\title{
Indonesian-English Code Mixing in Ria SW's Video Blog
}

ABSTRACT Video blogs or vlogs are stories of someone's daily life visualized and uploaded via YouTube. It managed to increase the most video uploads on YouTube. To attract the sympathy of the audience, the use of informal language or a relaxed variety was chosen to be more communicative. The data in this study were taken from Ria SW's vlog, one of the food vloggers with 2,700 subscribers. The use of two languages, Indonesian and English, turned out to attract and represent young people who are slang and intellectual speakers. Using two languages at once or referred to as code mixing, is a linguistic phenomenon that needs to be responded to using sociolinguistic theory to find forms of code-mixing in Ria SW's vlog. The method used in this research was a qualitative method. Through these methods and theories, it can be seen that RiaSW's use of Indonesian code-mixing. The type of code-mixing used by Ria SW is external code-mixing. The form of external code-mixing reflects the existence of high intellectual abilities and exudes moderate values. The form of code-mixing used is in the form of words, phrases and repetitions. The use of word types in code-mixing expressed by Ria SW is in nouns, verbs, and adjectives. The use of the noun form tended to mention the name of places and foods. The use of the verb form tended to invite, while the use of the adjective serves to explain the taste of the food. The causes of this communication strategy, the use of code-mixing in Ria SW's vlog are to get good communication by using more popular terms and letting the viewers understand the speaker code and the foreign terms of the tourism sector.

Keywords: code-mixing, video blog, food and drinks, Chiang Mai

INTRODUCTION Human ability to use language can be seen from knowledge (competence) and language usage (performance). Language competence is the knowledge possessed by language speakers about their language (Rusyana \& Samsuri 1978). Knowledge here means knowing and understanding the rules of a language in understanding and producing sentences, both acceptable and unacceptable sentences (Tarigan 2009). Meanwhile, performance is the use of language in actual conditions (Rusyana \& Samsuri 1978) in real situations both in written and spoken (Tarigan 2009). The competence and performance possessed by language speakers can be adjusted to their needs. There are two mainstream communities of Indonesian speakers communities; practitioners and linguistic. The practitioner community can speak Indonesian with fewer grammatical rules, while the linguist of Indonesian uses Indonesia with a good comprehension of grammar. The practitioner groups are more focused on aspects of casual and communicative situations. Emphasis on the performance aspect of Indonesian causes failures in mastering the correct linguistic rules so that if speakers of languages have competencies other than Indonesian, it can lead to grammatical mixing of other languages. This has become a linguistic phenomenon known as code-mixing.

In a multilingual society, most of the members of society master more than one language. If the mastery of the two languages is equally good, Bloomfield says that the speaker is bilingual (Chaer \& Agustina 2010). Bilingual speakers are speakers who have the ability or ability to master two languages (Nababan 1984). The level of mastery of two speaker's languages can be seen in terms of grammatical, lexical, and semantic, which is reflected 
in the four language skills; listening, reading, writing, and speaking. The interaction and intensive contact of these two languages result from codemixing or code-switching. Code-mixing is the use of two or more languages by incorporating elements of one language into another language (Suwito 1983).

The elements integrated with the language that is inserted as a whole only support one function. In code mixing, there is a principal or basic code used (Chaer \& Agustina 2010). The primary or basic code has a function and autonomy, while the other codes are only as pieces without having any function and autonomy. A prominent feature of code mixing is the presence of relaxation or in informal situations (Aslinda \& Syafyahya 2007). Informal situations cause code mixing in communication to be more effective and efficient (Widyaningtias 2018). In addition, the existence of specific topics in conversation; citing other people's conversations, expressing group identity, lexical needs that are not found in equivalent words (Putri 2017) or for mere prestige are also causes of code-mixing in speech (Ariesta 2019).

So far, research on the use of Indonesian in social media has become an important study for further research to determine language development. The use of Indonesian on social media, one of which occurs on WhatsApp social media, provides diversity in internal and external code mixing, which is called the presence of cognate and non-cognate language absorption elements (Sutarma 2017). The existence of code mixing that uses cognate languages is caused by the background and situation of the speakers, while those who use non-cognate languages (foreign languages) are caused by speakers who have mastered the foreign language (Nurlianiati, Hadi, \& Meikayanti 2019).

Research on the phenomenon of language usage in bilingual or multilingual communities is not a new one, especially research on social media that young people often use, one of which is video blog, or vlog. The research conducted (Saraswati 2020) analyzed code switching and code mixing by video blogger Nessie Judge who uses much external code-switching from Indonesian to English. This is because Nessie Judge's background is PakistaniChinese-Dutch, who is more familiar with English than Pakistani, Chinese, or Dutch. Interestingly, Nessie Judge can also speak Indonesian, and even Indonesian is her mother tongue, but due to the learning environment and the length of time she lived in Finland, she often uses English instead of Indonesian.

The background of speakers and speech partners mastering more than one language causes daily conversations to mix two languages, Indonesian and English often. This is also similar to the research conducted by (Fitria 2020) regarding code switching and code mixing in the video blog channel Genki Really! by Sokorahen Genki. The study found that the speakers came from Japan, and when living in Indonesia, the speakers used two languages, Indonesian and English. He uses English when he does not know the equivalent of words in Indonesian when carrying out daily conversations.

These two studies above are different from the research conducted by the author who chose video blogger Ria SW as the subject. The background of the speaker is a native Indonesian. However, in the use of language in the video, the blogger uses two languages (Indonesian and English) to explain the description of the location of a culinary place, the name of the food, and the taste of a food. Certain terms in describing food that use English aim to legitimate a food that is more prestige. This makes it different from other 
research since it uses two languages to explain culinary themes in Indonesia and abroad.

Based on the description of the background above, many things can be found through code mixing in Ria SW's video blog of culinary world, for example, it is found that there are forms of code mixing in the form of words, phrases, and the repetition of words. Therefore, research on Ria SW's stories uploaded on YouTube needs to be done to see the diversity of code-mixing forms and the causes of code mixing ocurrences in the blogger's videos, especially in culinary themes. By finding the diversity of code-mixing forms spoken by Ria SW, this research can contribute to language development, especially the languages of food vloggers who use code mixing forms as slang and intellectual self-image media.

THEORETICAL Noam Chomsky is well-known a pioneer of transformational linguistics. He REVIEW was the first to introduce transformational generative grammar. One of the

The Competence and Performance of Language Speakers results of his thinking is about competition and performance. Rusyana \& Samsuri (1978) define language competence or competence as the knowledge possessed by language speakers about their language. Chomsky argues that competence is a person's knowledge of the rules of a language in understanding and producing sentences, both acceptable and unacceptable sentences.

A person's understanding of unlimited abstract rules is the basis for linguistic behavior in analyzing and synthesizing correctly the relationship of sounds to the meaning of an indeterminate number of sentences (Tarigan 2009 , 21). Richards added that competence is a person's grammar in a language that is internalized to create and understand sentences, including understanding sentences that they have never heard before.

This case includes one's knowledge in identifying what is really a sentence and what is not a sentence (Tarigan 2009, 21-22). Meanwhile, according to Chomsky, the definition of performance is the actualization of language based on one's knowledge in real situations, both in speech and in writing (Tarigan 2009, 22).

The competence and performance possessed by language speakers are adjusted to their needs. There are groups of Indonesian speakers practically and groups of Indonesian speakers linguistically. The group of language speakers is practically able to speak Indonesian, but the language used is not much influenced by the language's grammar.

This is different from the linguistic group of Indonesian speakers who pay more attention to grammatical problems. Practically speaking, Indonesian groups are more focused on aspects of communicative situations. Emphasis on the performance aspect of the Indonesian language causes a failure in mastering the correct linguistic rules so that if a language speaker has competencies other than Indonesian, it can lead to a grammatical mixing of other languages. This has become a linguistic phenomenon known as code mixing in sociolinguistic terms.

Code Mixing Code mixing is using two or more languages by combining the elements of one language with the elements of another language. The integration of language elements with one another is carried out consistently. Kridalaksana $(2005,40)$ argues that code mixing is using one language unit with another, which expands language style or language variety, including the use of words, phrases, idioms, and greetings. 
In addition, Suwito(1983, 78-80) explains that in the integration of language elements with one another, there are several forms of insertion, namely insertion in the form of words, insertion in the form of phrases, insertion in the form of repeated words, insertion in the form of expressions or idioms, and insertion of clauses.

Suandi $(2014,143-46)$ divides the factors that cause code mixing in a speech into several categories, namely: the limited use of codes; the use of more popular terms; the speaker and the hearer's personality; topics, functions, and objectives; the variety and level of speech-language; the presence of the third party; the subject of conversation; the intention to create humor; and the purpose for achieving prestige.

RESEARCH This study uses qualitative methods intending to understand the phenomena METHOD in research subjects (Meleong 2009). This phenomenon is based on the facts contained in Ria SW's video blog. The material object of this research is Ria SW's speeches on her video blog uploaded on YouTube. Meanwhile, the formal object is the forms and the driving factors of the code mixing in Ria SW's speeches in the video blog.

The data source of this research is Ria SW's utterances in the form of sentences in the video blog. The videos selected were the videos filmed while Ria SW traveled in Korea, Japan, and Thailand. The selection was made based on the dominance of code mixing in the culinary videos of the three countries compared to culinary videos in Indonesia. There are three stages in this research; providing data, analyzing data, and presenting the results of data analysis. At the first stage, the data were obtained using the technique of listening. According to Sudaryanto (1993, 133), listening technique is an activity of collecting the data by recepting audio materials through hearing organs. In this study, the activity is directed to the speeches spoken by Ria SW in her video blog on YouTube.

The subsequent technique is note-taking. This is an advanced technique after the prior listening technique. It was done by recording the relevant data in accordance to the material object of the research (Mahsun 2012). The following technique is data analysis where all utterances containing code mixing are identified and then classified and categorized based on their similarities and differences. After being classified, the data were then analyzed based on the forms and the driving factors for code mixing.

DISCUSSION Based on the analysis of the speech in the culinary video blog of Ria SW, it is known that the dominant code-mixing speeches used is code-mixing in the form of words rather than phrases and word repetition. Coded word forms are dominantly used to mention the names, textures, and tastes of food. In addition, words are also dominantly used to mention the name of the place visited and the description of the situation encountered, such as 'crowded', 'explore', and 'jumping'. The argumentation that leads to the use of code mixing is to mention more popular terms, to convey information to people who do not understand the speaker code, and to convey foreign terms in tourism.

Code Mixing According to (Suandi 2014), there are two types of code mixing, external and in Ria SW's

Speech that have no kinship, either geographically or genealogically. 
The external type occurs because of the high intellectual ability and emits moderate values, while in internal code mixing, between the source and target languages there is a kinship relationship. The code mixing type in Ria SW's video is an external code-mixing type, which involves Indonesian and English language. Meanwhile, the forms of code-mixing in Ria SW's video blog comprise the insertion of elements in the form of words, phrases, and repetition of words.

Insertion of The insertion of code-mixing elements in the form of words in Ria SW's video word blog was found in the categories of nouns, verbs, and adjectives. The following is the insertion of elements in the form of nouns as follows.

(1) Kalau untuk hostelnya, aku pilih Heuan Pak Dee. Kenapa aku pilih ini? Sebenernya karena ada art gallery-nya gitu. (video timeline 2:40)

(For the hostel, I chose Heuan Pak Dee. Why did I choose this? Actually, because there is art gallery.)

(2) Kata orang lokal, kalau misalnya kita pergi ke Chiang Mai tapi kita enggak ke temple ini nih, itu katanya sama aja bo'ong kalian tuh gak ke Chiang Mai. (12:08)

(Local people say, if we go to Chiang Mai but we don't visit this is it, this temple, it means that you've lied or you haven't been in Chiang Mai.)

Data (1) and (2) show a mix of English codes in words and the noun category. In datum (1), Ria RW was traveling to Chiang Mai, Thailand. Ria SW chose a hostel called Heuan Pak Dee. In explaining the hostel selection, Ria SW mixed the code in English to mention the name of the place, namely the art gallery which is equivalent to galeri seni in Indonesian.

Similarly, in datum (2), she explained what local people say when they go to Chiang Mai. They must visit one of the places frequented by tourists, namely the temple, which is equivalent to candi in Indonesian. The types of words used in code mixing in data (1) and (2) are nouns. The noun category is used to mention the name of a place.

In addition to mentioning place names, there is also a code-mixing noun category spoken by her that serves to name food. The following datum shows the name of the food and the name of the object.

(3) Mienya kenyal, manis. Aduh, enak banget yah... beef-nya. (6:39)

(The noodle is so chewy, sweet. Ooops, it's very delicious.)

Code mixing in the form of words and categorized as nouns in datum (3) shows the insertion of English ino the speech in Indonesian. She mixed the code to name one of the types she ordered, 'beef', which is equivalent to daging sapi. In addition, she also mixed the code to mention one type of object name. The following data shows the existence of code mixing which has the function to mention the name of an object.

(4) Ini buat power bank. (1:27)

(It's for power bank.)

The code mixing in data (4) is in words and is categorized as nouns, namely by inserting English into Indonesian speech. The speech contains her explanation of the term of an object. In terms of equivalence, The Agency for Language Development and Books has provided the Indonesian equivalent of 'power bank' as bank daya.

However, the mention of code mixing in English has crystallized in the minds of the language-speaking community as the first language before the existence of its equivalent in Indonesian. 
In addition to the noun category, code mixing in the form of words in verb category are also found in Ria SW's video speech. The data are as follows.

(5) Mari kita explore! (0:41)

(Let's explore!)

(6) Ini kita jumping dulu ya. (0:57)

(This time we're jumping first.)

(7) Gak terlalu crowded gitu. (1:11)

(Not so crowded. Such that.)

Data (5) to (7) are code-mixing in the form of words categorized as verbs. In datum (5) Ria SW would start looking for food to be tasted by using a codemixing invitation in English to 'explore'. In datum (6), she found many places to eat and uses code mixing 'jumping'. In datum (7), she described the restaurant's atmosphere she visited by mixing the word 'crowded' that equals ramai in Indonesian.

The use of code mixing in the form of adjectives is also found in Ria SW's speech. The function of this category of adjectives is to describe the nature, texture, and taste of food. The data are as follows.

(8) Selain bahannya fresh, saosnya itu loh yang terkenal bikin nagih. (13:31)

(9) Pas digigit kan juicy ya. Tp manis banget sampai ke dalamnya. (16:16)

(10) Rasanya light, gak bikin enek. (15:45)

In data (8) to (10), there are word insertion elements from the adjective category in English, i.e. 'fresh', 'juicy', and 'light'. These three inserted elements describe the texture and taste of food. In datum (8), 'fresh' show the condition of the food whose ingredients have just been taken from their origins. Then, datum (9) describes the texture of a meat that is comparable tojuice. The condition of the 'juicy' textured meat is that the level of maturity is not too ripe. Meanwhile, in data (10), Ria SW describes the taste of a soup that is not too heavy by mixing the English code light, which means 'light'. Young people dominantly use the insertion of elements in the form of words in everyday language, especially those who live in urban areas and acquire two or more languages for specific purposes (Listyaningrum 2021).

Insertion of The forms code mixing in English phrases found in Ria SW's video blog are as phrase follows.

(11) Di sini tuh banyak banget makanan lokalnya. Salah satunya yang lagi dibuat ini. Tapi, sayangnya, aku dah coba dan gak cocok di lidah aku. Jadi, aku mau coba yang deep fried spring roll -nya aja. (16:08)

(Here, there are so many local food. Among others is the one that is being made. But, fortunately, I have tried and it does not match my tongue. So, I want to try the deep fried spring roll instead.)

(12) Malam ini khusus untuk coba makanannya! Salah satunya ada minuman yang antriannya panjang banget dengan harga yang udah pasti murah lah yah, coconut pudding with milk. (20:39)

(This night is dedicated to try its culinary! One of them is the drink whose queue is very long with the price that's, of course, cheap, coconut pudding with milk.)

(13) Curry noodle soup dengan potongan ayam. (22:13)

(Curry noodle soup with slices of chicken.)

From datum (11) to datum (13), an English code mixing element is inserted in the form of a noun phrase. In data (11) Ria SW was choosing some 
local Thai food. Ria SW prefered to name it 'deep fried spring roll'. In data (12), she wanted to buy a drink with many buyers queueing up, 'coconut pudding with milk'.

In addition to buying snacks and drinks, she also bought heavy meals by inserting an element of mixed English code, that is 'curry noodle soup'.In contrast with Listyaningrum's (2021) research, the use of code mixing in the form of phrases is only found for mentioning names. In this study, the dominant insertion of phrasal elements is for mentioning the names of food.

Insertion of Mixing code by inserting elements of word repetition can also be found in Ria word repetition SW's video blog. The data are as follows.

(14) Pas diselimuti sama seladanya, rasanya enak banget. Kayak jadi crunchycrunchy gitu (5:17)

(As it's covered with the salad, the taste is very delicious. It's becoming crunchy-crunchy.)

In datum (14), Ria SW described the food texture in Indonesian as crunchy when it is chewed. She looked more familiar the term 'crunchy' rather than its Indonesian equivalent garing. Code mixing in everyday language is considered natural because of bilingual abilities of the speakers (Rizkita \& Wirawati 2021). With the insertion of code mixing elements in the form of words, phrases, and repetition, the speaker likely wants to show their capability in English, so that when using several terms in English, he/she is judged to be more intelligent and has superior values.

The Causes of Code Mixings in Rini SW's Vlog

The factor that causes code mixing in Ria SW's video blog is her tendency to communicate casually. The forms of casual varieties include: using popular terms, using terms that are easily understood by people who do not master the speaker code, and using general terms in tourism. This use of casual communication cannot be separated from Ria SW's background as a resident of Jakarta, so that in daily activities, she uses a casual variety of Indonesian.

The use of more Popular terms are words/phrases that have widely been agreed upon by popularterms speakers to be used as terms everyone understands. The data showing the use of more popular terms in Ria SW's video blog are as follows.

(15) Kalau dessert, kayaknya aku mau minum aja deh. Jadi, aku milih coconut milkshake (17:39)

(For the dessert, I think I just want to drink. So, I chose coconut milkshake.)

In her video blog, Ria SW traveled around Indonesia and abroad to find culinary delights. One of the destinations was Thailand, precisely in Chiang Mai. On the location, there were several names for food and drinks in English. In datum (15) Ria SW was looking for a typical drink of Thailand and in Chiang Mai there is a drink called 'coconut milkshake'.

The drink is made up of coconut water which is mixed with milk. The term 'milkshake' has become a collective agreement amids the global community to name any drink that is mixed with milk. In Indonesia, various drinks with the name 'milkshake' have also been popular, such as chocolate milkshake, strawberry milkshake, vanilla milkshake, oreo milkshakes, and so on.

In addition to popular terms that refer to food or drinks, some refer to other things. Here is another datum showing the use of more popular term.

(16) Sekarang kita ke tempat shopping terbesar di Bangkok. (2:21)

Now, we go to the biggest shopping center in Bangkok.) 
Delivering Regional differences are one of the causes of differences in language codes. information to who do not know the speaker's code

In datum (16) the word 'shopping' is a term that has been popularly used by people globally. The public use the term 'shopping' to designate a more specific term, like shopping for clothes, bags, shoes or accessories which is done at shopping centers, such as stores, malls or the web which is often referred to as online shops.

Therefore, there are several codes mutually agreed upon by the global community to convey the same information. The data that showthe driving factors for code mixing to convey information to people who do not master the code of speakers are as follows.

(17) Thailand itu kan terkenal banget sama street food-nya, night marketnya. Di Chiang Mai ini banyak banget night marketnya. (0:04)

(Thailand is very famous for its street food, its night market. Here in Chiang Mai, there are so many night markets.)

The terms 'street food' and 'night market' in datum (17) indicate code mixing in English. The term 'street food' means food or drinks sold on the roadside using tents or kiosks that are easy to clean up. It has become a global term that is understood by the global community. Likewise, the term 'night market', as in the words that make it up, means a place for selling and buying available at night.

In Indonesia, the term is popularly known as pasar malam that is a market opened from the evening up to midnight. A pasar malam commonly sells food, drinks, and goods at low prices. In addition, there are rides for children to play. Ria SW prefered using the global terms, 'street food' and 'night market', to convey the information on culinary tourism in Chiang Mai.

Stating foreign terms of tourism
Another driving factors for code-mixing in a speech is the presence of foreign terms in the tourism sector. The data that mentions foreign terms in the tourism sector are as follows.

(18) Selain makanan, disini juga ada toko fashion, sarung bantal, sabun sampai aksesoris (16:45)

(Besides food, there are also fashion, pillow case, soap, up to accessories stores.)

(19) Oh, mereka juga jual merchandise. Pas aku ke sini, lagi buy one get one free. One-nya terserah mau rasa apa (18:25)

(Oh, they also sell merchandise. When I'm here, it's being 'buy one get one free'. The 'one' is free for any flavor.)

(20) Ini kan market-nya gede banget dan luas banget. Mereka punya 27 sektor gitu. Jadi, sebelum kita explore, kita harus liat maps-nya! (0:33)

This market is very big and very large. They have 27 sectors in total. So, before we explore, we have to see its maps.)

From datum (18) to (20), there are three foreign terms in tourism, namely 'fashion', 'merchandise' and 'market'. Fashion is related to clothings and its accesories, merchandise is a gift or souvenir, whereas market is a place for selling and buying. These three foreign terms are often encountered when we are traveling abroad.

The blind spot of this research lies in taking the object of study, which focused on the Ria SW's vlogs filmed in a foreign country, so that the dominant forms of code mixing found to be the external or outgoing only. The researcher did not take the videos of Ria SW's culinary reviews in Indonesia. 
For further study, it is needed to get a comparison between how she speaks abroad and in Indonesia, so that we can draw a more comprehensive understanding.

CONCLUSION Based on the analysis above, it can be concluded that social media can affect language competence and performance. The performance or actual use of language on social media uses non-standard language or casual variety that makes conversations more communicative. Through sociolinguistic analysis, the phenomena of code mixing on social media, especially in Ria SW's YouTube channel, could be found. The type of code mixing found is the external one that reflects high intellectual abilities and emits moderate values.

The forms of code mixing performed by Ria SW in her video blog is by inserting words, phrases, and repetitions. The words inserted include nouns, verbs, and adjectives. The noun category shows the name of the food and place, the verb category represents an invitation, whereas the adjective category indicates the taste and texture of food.

The factors causes code mixing in Ria SW's video blog are using more popular terms, to delivery of information to people who do not master the speaker's code, and to mention foreign terms in the tourism sector.The findings may vary when there is future research taking Ria SW's speech in her video blog in Indonesia setting as a comparison on the forms and types of code mixing she uses.

Ariesta, Nisya Ayu. 2019. Bentuk dan Faktor Campur Kode dalam Video Youtube Kaesang Tahun 2017 (Thesis). Universitas Sanata Dharma. https://repository.usd.ac.id/35078/

Aslinda \& Leni Syafyahya. 2007. Pengantar Sosiolinguistik. Bandung: Refika Aditama

Chaer, Abdul \& Leonie Agustina. 2010. Sosiolinguistik: Suatu Pengantar. Jakarta: Rineka Cipta

Fitria, Fatmalaldatul. 2020. Alih Kode dan Campur Kode dalam Video Blog Channel Genki Banget! oleh Sokorahen Genki (Tesis). Surabaya: Universitas Airlangga. https://repository.unair.ac.id/97182/

Kridalaksana, Harimurti. 2005. Kamus Linguistik. Jakarta: Gramedia Pustaka Utama

Listyaningrum, Lala. 2021. "Campur Kode dalam Review Produk Kecantikan oleh Ririe Prams di YouTube." Caraka 7 (2): 94-103. doi:10.30738/caraka.v7i2.9679

Mahsun. 2012. Metode Penelitian Bahasa: Tahap Strategi, Metode, dan Tekniknya. Jakarta: Raja Grafindo Persada

Moleong, Lexy J. 2009. Metode Penelitian Kualitatif. Bandung: PT Remaja Rosdakarya

Nababan, PWJ. 1984. Sosiolinguistik: Suatu Pengantar. Jakarta: Gramedia Pustaka Utama

Nurlianiati, Miftakhus Sholikhah, Panji Kuncoro \& Ermi Adriani Meikayanti. 2019. "Campur Kode dan Alih Kode dalam Video YouTube Bayu Skak." Widyabastra: Jurnal Ilmiah Pembelajaran Bahasa dan Sastra Indonesia 7 (1): 1-8

Putri, Anugrah Giska. 2017. Campur Kode dalam Video Minyo33 (Indonesian Beauty Vlogger): Kajian Sosiolinguisti (Thesis). Bandung: Universitas Widyatama

Rizkita, Ginisillen Novif, \& Denik Wirawati. 2021. "Campur Kode dalam Youtube Suhay Salim dan Kaitannya dengan Bahan Ajar Teks Iklan". Jurnal Idiomatik 4 (1): 16-20. doi:10.46918/idiomatik.v4il.1000

Rusyana, Yus \& Samsuri. 1978. Pedoman Penulisan Tata Bahasa Bahasa Indonesia. Jakarta: Departemen Pendidikan dan Kebudayaan. http://repositori.kemdikbud. go.id/id/eprint/3293

Saraswati, Candra Dewi. 2020. Alih Kode dan Campur Kode dalam Video Blogger Nessie Judge. Preprint. INA-Rxiv. doi:10.31227/osf.io/trux4

Suandi, I Nengah. 2014. Sosiolinguistik. Yogyakarta: Graha IImu.

Sudaryanto. 1993. Metode dan Aneka Teknik Analisis Bahasa: Pengantar Penelitian Wahana Kebudayaan Secara Linguistis. Seri ILDEP. Yogyakarta: Duta Wacana University Press. 
Sutarma, I Gusti Putu. 2017. "Campur Kode dalam Penggunaan Bahasa Indonesia di Media Sosial Whatsapp" Soshum: Jurnal Sosial dan Humaniora 7 (2): 189-201. doi:10.31940/soshum.v7i2.593

Suwito. 1983. Sosiolinguistik: Pengantar Utama. Surakarta: Universitas SebelasMaret

Tarigan, Henry Guntur. 2009. Pengajaran Kompetensi Bahasa. Bandung: Penerbit Angkasa

Widyaningtias, Risma. 2018. Alih Kode dan Campur Kode dalam Video Blogger: Kajian Sosiolinguistik (Skripsi). Semarang: Universitas Diponegoro. http://eprints.undip.ac.id/ 63508/

\section{ARTICLE CITATION IN THE CHICAGO MANUAL OF STYLE 16}

\section{In-text Citation}

Ulfiana $(2021,119) \ldots .$.

..... (Ulfiana 2021, 119)

\section{Reference List Entry}

Ulfiana, Elita. 2021. "Indonesian-English Code Mixing in Ria SW's Video Blog". Leksema: Jurnal Bahasa dan Sastra 6 (2): 115-124. https://doi.org/10.22515/ljbs.v6i2.3371.

\section{Copyright (C) 2021 Leksema: Jurnal Bahasa dan Sastra}

